\title{
Implementasi Model-Model Pembelajaran Penjas dalam Meningkatkan Kemampuan Guru Memilih dan Mengembangkan Strategi Pembelajaran Pendidikan Jasmani Olahraga dan Kesehatan
}

\author{
Resty Gustiawati \\ Universitas Singaperbangsa, H.S Ronggowaluyo Teluk Jambe Timur, Karawang 41361
}

*Corresponding author: resty.gustiawati@gmail.com

\author{
ART ICLE INFO \\ Article history: \\ Received 12 August 16 \\ Received in revised form 26 Agustus 16 \\ Accepted 16 September 16
}

Keywords:

Physical Education Learning Models;

Teacher Ability; Learning Strategy

\begin{abstract}
A B S T R A C T
The research method used a qualitative approach to the type of ethnographic research. Researcher using purposive sampling technique and Snowball Sampling. The first informant research location in Vocational School District 1 Karawang, second informant in vocational Rosma Karawang, and the third informant in vocational BANKING Karawang, Karawang, West Java.

Results of analysis of research data, Teacher Competence in Conducting Assessment and Learning Evaluation of Physical Education In Teacher of Physical Education Vocational High School in Karawang, shows that teachers of Physical Education tends to be more organized assessment and evaluation only at the end of the lesson, namely the assessment and evaluation of learning outcomes of physical education.
\end{abstract}

\section{Pendahuluan}

Kecenderungan masa depan yang semakin rumit dan kompleks tampaknya mengharuskan pendidikan untuk mampu menyiapkan siswa dalam menghadapi dunia nyata (Sutrisno, 2005: 36). Di sekolah, siswa perlu disadarkan tentang harapan yang mereka pikul, tantangan yang mereka hadapi dan kemampuan yang perlu mereka kuasai. Akan tetapi upaya perbaikan apapun yang dilakukan untuk meningkatkan kualitas pendidikan tidak akan memberikan sumbangan yang signifikan tanpa didukung oleh guru yang berkualitas (E. Mulyasa, 2007: 5). Masyarakat/ orang tua murid pun kadang-kadang mencemoohkan dan menuding guru tidak kompeten, tidak berkualitas, manakala putra-putrinya tidak bisa menyelesaikan persoalan yang ia hadapi sendiri atau memiliki kemampuan tidak sesuai dengan kemampuannya. Rendahnya pengakuan masyarakat terhadap profesi guru sudah sampai pada titik nadir.

Salah satu faktor yang mengakibatkan rendahnya pengakuan masyarakat terhadap profesi guru yakni kelemahan yang terdapat pada diri guru itu sendiri, diantaranya rendahnya tingkat kompetensi profesionalisme mereka (Moh Uzer Usman, 2001:3). Penguasaan guru terhadap materi dan metode pengajaran masih berada dibawah standar. Hal tersebut didukung dengan hasil penelitian Balitbang Kemendikbud RI diantaranya menunjukkan bahwa kemampuan membaca para siswa kelas VI SD di Indonesia masih rendah. Kegagalan tersebut disebabkan pengajaran guru hanya mementingkan penguasaan huruf tanpa penguasaan makna. Kemudian dalam survey tentang pendekatan metode pembelajaran yang di gunakan oleh guru pada proses pembelajaran, guru sebagian besar tampaknya cenderung menjawab bahwa pendekatan yang sering digunakan adalah pendekatan pembelajaran konvensional dengan kekuatan intinya pada penggunaan metode ceramah (Chalk and Talk Approach)

Kegiatan pembelajaran, dalam implementasinya mengenal banyak istilah untuk menggambarkan cara mengajar yang akan dilakukan oleh guru. Saat ini, begitu banyak macam strategi ataupun metode pembelajaran yang bertujuan untuk meningkatkan kualitas pembelajaran menjadi lebih baik. Berkaitan dengan permasalahan implementasi pendekatan dan metode pembelajaran mutakhir (model-model pembelajaran siswa aktif) dalam KBK dan KTSP, setidaknya saya melihat ada dua sisi permasalahan yang berbeda, tetapi tidak bisa dipisahkan, yaitu, masalah keterbatasan keterampilan (kemampuan) dan masalah keterbatasan motivasi (kemauan).

Berdasarkan kondisi tersebut, masalah pelakasanaan Implementasi modelmodel pembelajaran yang bervariasi dengan konsep yang berbeda-beda yang sangat bermanfaat bagi perkembangan siswa dalam aspek kognitif, afektif dan psikomotornya. Sehingga guru perlu menerapkan model-model pembelajaran penjas yang cocok sesuai dengan materi ajarnya. Sedangkan ada sebagian guru yang belum memiliki kemampuan dalam memilih dan mengembangkan suatu strategi mengajar, dengan belum mengetahui dan memahami model-model pembelajaran penjas yang bervariasi tersebut, dan sebagian lagi guru yang sudah mampu menerapkan model-model tersebut, namun enggan untuk melaksanakannya, dikarenakan dengan alasan beberapa faktor.

\subsection{Rumusan Masalah}

Untuk lebih terarahnya penelitian ini, penulis merumuskan masalah penelitian sebagai berikut.

1. Apakah Model-Model Pembelajaran Penjas telah di Implementasikan oleh Guru Penjasorkes Sekolah Menengah Pertama PGRI di Kecamatan Tegalwaru Kabupaten Karawang?

2. Bagaimana Kemampuan Guru Penjasorkes dalam Memilih dan Mengembangkan Strategi Pembelajaran Pada Sekolah Menengah Pertama PGRI di Kecamatan Tegalwaru Kabupaten Karawang? 


\subsection{Tinjauan Pustaka}

Kemampuan Guru dalam Strategi Pembelajaran dan Pemilihannya 1. Pengertian Strategi Pembelajaran

Secara spesifik guru harus memiliki kemampuan dalam mengembangkan strategi pembelajaran, serta dapat memilih strategi yang tepat dalam kegiatan pembelajaran. Strategi merupakan usaha untuk memperoleh kesuksesan dan keberhasilan dalam mencapai tujuan. Dalam dunia pendidikan strategi dapat diartikan sebagai $a$ plan, method, or series of activities designed to achieves a particular educational goal (J. R. David, 1976).

Strategi pembelajaran dapat diartikan sebagai perencanaan yang berisi tentang rangkaian kegiatan yang didesain untuk mencapai tujuan pendidikan tertentu. Strategi pembelajaran merupakan rencana tindakan (rangkaian kegiatan) termasuk penggunaan metode dan pemanfaatan berbagai sumber daya atau kekuatan dalam pembelajaran yang disusun untuk mencapai tujuan tertentu. Dalam hal ini adalah tujuan pembelajaran. Begitu juga seorang guru yang mengharapkan hasil baik dalam proses pembelajaran juga akan menerapkan suatu strategi agar hasil belajar siswanya mendapat prestasi yang terbaik. Strategi pembelajaran adalah suatu kegiatan pembelajaran yang harus dikerjakan guru dan siswa agar tujuan pembelajaran dapat dicapai secara efektif dan efisien. Kemp (1995). Dilain pihak Dick \& Carey (1985) menyatakan bahwa strategi pembelajaran adalah suatu set materi dan prosedur pembelajaran yang digunakan secara bersama-sama untuk menimbulkan hasil belajar pada siswa.

Strategi pembelajaran merupakan hal yang perlu di perhatikan oleh seorang instruktur, guru, widyaiswara dalam proses pembelajaran. Paling tidak ada 3 jenis strategi yang berkaitan dengan pembelajaran, yakni: (a) strategi pengorganisasian pembelajaran, (b) strategi penyampaian pembelajaran, dan (c) strategi pengelolaan pembelajaran.

\section{Istilah-istilah dalam Strategi Pembelajaran}

Dalam proses pembelajaran dikenal beberapa istilah yang memiliki kemiripan makna, sehingga seringkali orang merasa bingung untuk membedakannya. Istilah-istilah tersebut adalah: (1) pendekatan pembelajaran, (2) strategi pembelajaran, (3) metode pembelajaran, (4) teknik pembelajaran, (5) taktik pembelajaran, dan (6) model pembelajaran. Berikut ini akan dipaparkan pengertian istilah - istilah tersebut, dengan harapan dapat memberikan kejelasaan tentang penggunaan istilah tersebut.Beberapa istilah yang hampir sama dengan strategi yaitu metode, pendekatan, teknik atau taktik dalam pembelajaran.

Apabila antara pendekatan, strategi, metode, teknik dan bahkan taktik pembelajaran sudah terangkai menjadi satu kesatuan yang utuh maka terbentuklah apa yang disebut dengan model pembelajaran. Jadi, model pembelajaran pada dasarnya merupakan bentuk pembelajaran yang tergambar dari awal sampai akhir yang disajikan secara khas oleh guru. Dengan kata lain, model pembelajaran merupakan bungkus atau bingkai dari penerapan suatu pendekatan, metode, dan teknik pembelajaran.

Berkenaan dengan model pembelajaran, Bruce Joyce dan Marsha Weil (Dedi Supriawan dan A. Benyamin Surasega, 1990) mengetengahkan 4 (empat) kelompok model pembelajaran, yaitu: (1) model interaksi sosial; (2) model pengolahan informasi; (3) model personal-humanistik; dan (4) model modifikasi tingkah laku. Kendati demikian, seringkali penggunaan istilah model pembelajaran tersebut diidentikkan dengan strategi pembelajaran.

Untuk lebih jelasnya, posisi hierarkis dari masing-masing istilah tersebut, kiranya dapat divisualisasikan sebagai berikut:

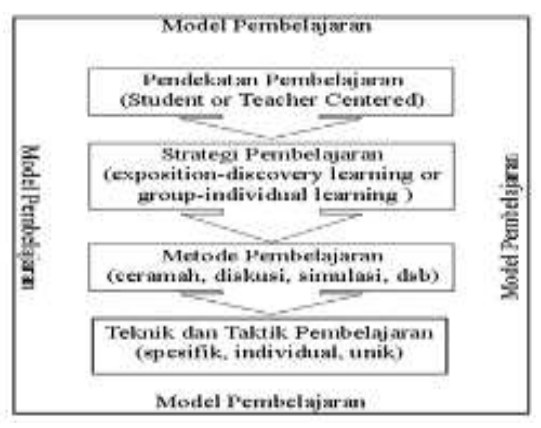

Gambar 2.1. Posisi Hierarkis dalam Model Pembelajaran

Berdasarkan uraian di atas, bahwa untuk dapat melaksanakan tugasnya secara profesional, seorang guru dituntut dapat memahami dan memliki keterampilan yang memadai dalam mengembangkan berbagai model pembelajaran yang efektif, kreatif dan menyenangkan, sebagaimana diisyaratkan dalam Kurikulum Tingkat Satuan Pendidikan.

\section{B. Model Pembelajaran Penjas}

Pendidikan jasmani olahraga dan kesehatan yang diajarkan disekolah memiliki peranan sangat penting, yaitu memberikan kesempatan kepada perserta didik. Untuk terlibat langsung dalam berbagai pengalaman belajar melalui aktivitas jasmani, olahraga, dan kesehatan yang terpilih yang dilakukan secara sistematis. Namun demikian pemahaman yang mendalam dan menyeluruh terhadap konsep saja ternyata tidak cukup untuk dapat mengajar pendidikan jasmani secara efektif. Para guru harus juga memahami model pembelajaran. Model pembeljaran sebernarnya adalah model belajar (models of teaching are really models of learning) Bruce and Marsa (1996). Mereka mendefinisikan model pembelajaran sebagai pengorganisasian lingkungan yang dapat menggiring siswa berinteraksi dan mempelajari bagaimana belajar. Oleh karena setiap siswa adalah unik memiliki cara belajar yang beragam sesuai dengan perkembangan dan latar belajar sejarahnya, maka model pembeljaran yang berkembang sangat beragam. Bruce and Marsha (1996), mengungkap tidak kurang dari 18 model pembelajaran, modelmodel tersebut dapat dipilih atau dikombinasikan untuk diterapkan dalam proses pembelajaran pendidikan jasmani.

\section{Proses Pembelajaran Pendidikan Jasmani}

Proses pembelajaran pada dasarnya merupakan interaksi pedagogis antara guru, siswa, materi, dan lingkungannya. Muara dari proses pembelajaran adalah siswa belajar. Secara garis besar proses ini dapat dibagi ke dalam tiga kategori pengelolahan yaitu pengelolaan rutinitas, pengelolaan inti proses belajar, serta pengelolaan lingkungan dan materi pembelajaran.

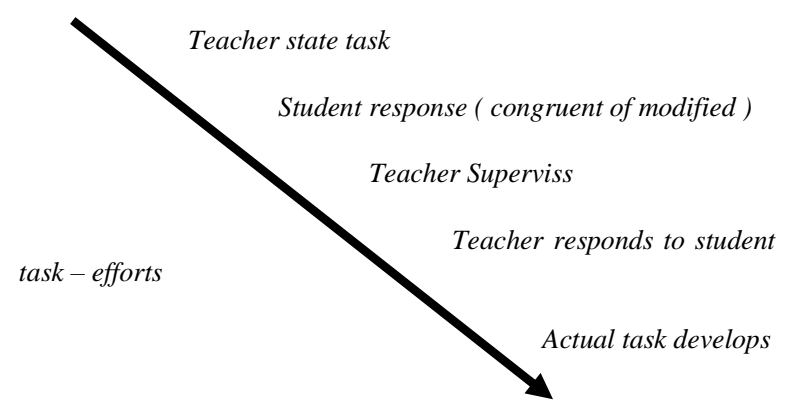

Gambar 2.2

Pengelolaan Inti Proses Belajar Pendidikan Jasmani Siedentop (1991)

\section{Episode Pembelajaran Pendidikan Jasmani}

Pengelolaan dan pemahaman tentang keterampilan mengajar dan pengelolaan proses pembelajaran yang efektif harus dilanjutkan 
dengan usaha penerapan manakala para guru berharap ingin meningkatkan kemampuan mengajarnya. Perencanaan implementasi pembaruhan pembelajaran harus dibuat sesuai dengan kebutuhannya. Suatu model perencanaan yang cocok untuk tujuan tertentu belum tentu cocok untuk tujuan lainnya untuk itu, diperlukan pemahaman yang memadai mengenai episode dan keterampilan mengajar pendidikan jasmani secara komprehensif sehingga kita dapat secara spesifik menentukan episode dan target pembaruhan yang akan dilakukanya.

\section{Model-Model Pembelajaran Kooperatif}

\section{a. Model Pembelajaran Kooperatif Tipe Teams Games Tournament \\ Menurut Saco, 2006 (dalam Rusman, 2011) dalam teams} anggota tim lain untuk memperoleh skor bagi tim mereka masing-masing. Permainan dapat disusun guru dalam bentuk kuis berupa pertanyaan-pertanyaan yang berkaitan dengan materi pelajaran ataupun dalam bentuk perintah gerak. Kadangkadang juga dapat juga diselingi dengan pertanyaan yang berkaitan dengan kelompok (identitas kelompok mereka)

\section{b. Model Pembelajaran Kooperatif Tipe Jigsaw}

Pengertian Model Pembelajaran Kooperatif Jigsaw, Model pemebelajaran kooperatif tipe jigsaw adalah sebuah model belajar kooperatif yang menitik beratkan kepada kerja kelompok siswa dalam bentuk kelompok kecil, seperti yang diungkapkan Lie ( 1993: 73), bahwa pembelajaran kooperatif model jigsaw ini merupakan model belajar kooperatif dengan cara siswa belajar dalam kelompok kecil yang terdiri atas empat sampai dengan enam orang secara heterogen dan siswa bekerja sama salaing ketergantungan positif dan bertanggung jawab secara mandiri.

\section{c. Model Pembelajaran PBI (Problem Based Instruction)} pengajaran dengan pendekatan pembelajaran siswa pada masalah autentik. Masalah autentik dapat diartikan sebagai suatu masalah yang sering ditemukan siswa dalam kehidupan seharihari. Dengan metode Problem Based Instruction (PBI) siswa dapat dilatih menyusun sendiri pengetahuannya, mengembangkan keterampilan pemecahan masalah, mandiri serta meningkatkan kepercyaan diri. Selain itu dengan pemberian masalah autentik, siswa dapat membentuk makna dari bahan pembelajaran melalui proses belajar dan menyimpannya dalam ingatan sehingga sewaktu-waktu dapat digunakan lagi (Nurhadi , 2004). Dengan demikian dapat di rumuskan bahwa guru sebagai pendidik harus mampu menerapkan model pembelajaran penjas yang bervariatif, lebih mandiri, sehingga kemampuan guru dalam memilih dan mengembangkan strategi Pembelajaran lebih meningkat yang menjadikan proses pembelajaran yang lebih baik lagi. game tournament murid memainkan permainan dengan anggota-

Problem Based Instruction (PBI) adalah suatu model menyenangkan, dan lebih merangsang perkembangan siswa

model-model pembelajaran penjas dalam meningkatkan kemampuan guru memilih dan mengembangkan strategi pembelajaran penjasorkes.

\section{Penerapan Model-Model Pembelajaran Penjas Oleh Guru}

\section{Penjasorkes}

Berdasarkan data hasil penelitian yang dilakukan melalui wawancara terhadap responden penelitian, terungkap bahwa 33,33\% informan yang mengelola kegiatan rutinitas awal dan akhir pembelajaran dengan baik. $100 \%$ informan mengelola inti Proses pembelajaran dengan baik. 66,33\% Informan mengelola lingkungan yaitu yang berkaitan dengan alat, ruang/ tempat, dan waktu dengan baik. 66,33\% informan sangat mementingkan bagaimana materi itu terjabarkan sehingga peserta didik dapat menguasai tugas gerak yang disajikan oleh guru. 100\% Informan mengetahui apa yang dimaksud dengan Episode pembelajaran dalam penjas yaitu sebagai suatu langkah-langkah yang selalu dilalui dalam setiap pertemuan dalam pembelajaran penjas. $0 \%$ dari informan yang mengerti dan menerapkan suatu kesatuan dari pendekatan, strategi, metode, teknik, dan gaya pembelajaran dalam suatu bingkai yang sudah terangkai. Tidak ada informan yang bisa menyebutkan model-model pembelajaran yang biasa diterapkan dalam penjas di lapangan dan informanpun belum dapat menjelaskan bagaimana suatu model pembelajaran penjas itu diimplementasikan.

\section{Kemampuan Guru Penjasorkes dalam Memilih dan Mengembangkan Strategi Pembelajaran}

Berdasarkan data hasil penelitian yang dilakukan melalui wawancara terhadap informan penelitian, terungkap bahwa 30,33\% dari informan paham akan definisi konsep dari strategi pembelajaran itu sendiri. $100 \%$ informan menyampaikan isi pembelajaran dengan sistematis dan sesuai dengan perencanaan yang telah dibuat secara konsep jauh sebelum pembelajaran dimulai. $100 \%$ informan menyediakan media pembelajaran yang diperlukan peserta didik dalam inti proses pembelajaran sebelum penyajian materi dilapangan di mulai. $100 \%$ informan memiliki catatan kemajuan belajar siswa untuk mengetahui peningkatan prestasi siswa dalam pembelajaran penjas. $100 \%$ informan menyatakan melakukan kegiatan yang menimbulkan motivasi siswa untuk lebih bersemangat sebelum pembelajaran penjas dimulai. $66,33 \%$ informan mengetahui tentang istilah-istilah beserta pengertian dan ciri-ciri khas dari istilah tersebut, seperti istilah Pendekatan pembelajaran, strategi pembelajaran, metode pembelajaran, teknik pembelajaran, dan taktik/ gaya pembelajaran penjas. $33,33 \%$ informan yang mengetahui tentang bagaimana penerapan pendekatan pembelajaran yang berpusat pada siswa. $66,33 \%$ informan paham akan bagaimana membuat suatu strategi pembelajaran yang efektif dilapangan. $100 \%$ informan mengetahui dan memahami penerapan suatu metode pembelajaran dalam proses pembelajaran penjas. $100 \%$ informan menerapakan berbagai macam metode pembelajaran yang berbeda saat pembelajaran penjas berlangsung. $66,33 \%$ informan mengetahui bagaimana melaksanakan teknik pembelajaran saat proses pembelajaran penjas berlangsung sesuai dengan kondisi di lapangan. $66,33 \%$ menunjukkan gaya pembelajaran yng diciptakan dalam proses pembelajaran penjas adalah gaya humoris dan enjoyed sehingga siswa lebih fun dalam mengikuti pembelajaran penjas di lapangan.

\section{Kesimpulan dan Saran}

\section{Metode Penelitian}

Penelitian ini menggunakan metode penelitian kualitatif dengan menggunakan pendekatan jenis penelitian etnografi. Peneliti menggunakan teknik Purposive Sampling dan Snowball Sampling dalam menentukan subjek penelitian yaitu guru Penjasorkes di sekolah menengah pertama PGRI Pangkalan Kecamatan Tegalwaru Kabupaten Karawang, Jawa Barat. Jenis Data Penelitian yang digunakan yaitu buku catatan, rekaman video, dokumentasi, dan foto. Pengumpulan data dilakukan dengan teknik observasi, wawancara, dan studi dokumentasi.Teknik analisis data dalam penelitian ini menggunakan Model Sirkuler Nasution, yaitu pertanyaan penelitian, pengumpulan data, analisis data, verifikasi, dan laporan berdasarkan catatan dan ingatan. Keabsahan data dilakukan dengan triangulasi kepada kepala sekolah, rekan guru, dan siswa.

Hasil penelitian untuk mengetahui bagaimana implementasi
Berdasar kepada hasil-hasil penelitian dan pembahasannya, maka dapat disimpulkan bahwa,

1. Penerapan Model-Model Pembelajaran Penjasorkes Oleh Guru Kecamatan Tegalwaru Karawang dapat dinyatakan belum menerapkan model-model pembelajaran penjas di dalam proses pembelajaran di lapangan. Dengan fakta guru belum dapat menyebutkan jenis-jenis model pembelajaran dan penerapannya di lapangan. Sehingga guru belum dapat menerapkan dan menyajikan materi pembelajaran secara khas kepada siswa.

2. Kemampuan Guru Penjasorkes Dalam Memilih Dan Mengembangkan Strategi Pembelajaran Pada Sekolah Menengah Pertama PGRI Pangkalan Kecamatan Tegalwaru Penjas di Sekolah Menengah Pertama PGRI Pangkalan 
Karawang dapat dinyatakan guru memiliki kemampuan yang cukup baik dalam memilih dan mengembangkan strategi pembelajaran penjas dilapangan. Guru mengetahui strategi pengorganisasian pembelajaran dan mengetahui istilah-istilah dalam strategi pembelajaran namun belum diimplementasikan ke dalam proses pembelajaran sehingga peningkatan kemampuan guru dalam memilih dan mengembangkan strategi pembelajaran belum optimal. Sehubungan dengan kesimpulankesimpulan tersebut, maka saran-saran yang dapat dikemukakan dalam penelitian ini sebagai berikut:

1. Dinas Pendidikan khususnya dalam bidang pendidikan jasmani dan kesehatan, untuk mengadakan suatu seminar ataupun pelatihan guru penjas untuk meningkatkan profesinalisme dan kinerja guru dalam proses pembelajaran.

2. Kepala Sekolah hendaknya mengikutsertakan guru penjas kedalam beberapa acara seminar dan pelatihan khusus guru pendidikan jasmani olahraga dan kesehatan, agar guru penjas senantiasa memiliki kemampuan yang baik dalam mengimplementasikan model pembelajaran yang beragam dan lebih kreatif dan inovatif.

3. Guru pendidikan jasmani olahraga dan kesehatan hendaknya lebih terbuka dalam menghadapi suatu perubahan kearah yang lebih baik untuk kepentingan profesionalisme, kualitas pembelajaran, dan peningkatan prestasi siswa yang optimal.

\section{Daftar Pustaka}

Arikunto, Suharsimi. 2002. Prosedur Penelitian: Suatu Pendekatan Praktek, Jakarta: PT. Rineka Cipta.

Bruce, Joyce. Et al. 2000. Models of Teaching. 6th Ed. Allyn \& Bacon: London

Djam'an Sutori. 2009. Metodologi Penelitian Kualitatif, Bandung: Alfabeta.

Hamalik, Oemar. 1990. Metode Belajar dan Kesulitan-Kesulitan Belajar. Bandung: Tarsito

Hamzah B. Uno . 2006. Perencanaan Pembelajaran. Jakarta: Bumi
Aksara.

Husdarta. 2009. Manajemen Pendidikan Jasmani, Bandung: Alfabeta.

Ibrahim R, Syaodih S Nana. 2003. Perencanaan Pengajaran. Jakarta: Rineka Cipta.

Nasution. S. 2005. Berbagai Pendekatan dalam Proses Belajar dan Mengajar. Jakarta: Bumi Aksara.

Nasution. 1988. Metode Penelitian Naturalistik Kualitatif, Bandung: Tarsito.

Nazir. 2003. Metode Penelitian, Jakarta: Ghalia Indonesia.

Purwanto, Ngalim. 2002. Prinsip-Prinsip dan Teknik Evaluasi Pengajaran, Bandung: PT. Remaja Rosdakarya

Riduwan. 2006. Belajar Mudah Penelitian Untuk Guru-Karyawan dan Pemula, Bandung: Alfabeta.

Rusman. 2012. Model-Model Pembelajaran: Mengembangkan Profesionalisme Guru Edisi Ke Dua. Jakarta: Rajawali Pers.

Sanjaya, Wina. 2006. Strategi Pembelajaran. Jakarta: Media Prenada.

Singarimbun, Masri. 2006. Metode Penelitian Survai, Jakarta: LP3ES Indonesia.

Sudjana, Nana. 1989. Cara Belajar Siswa Aktif dalam Proses Pembelajaran. Bandung: Sinar Baru.

Sudjana, Nana. 2010. Penilaian Hasil Proses Pembelajaran, Bandung: PT. Remaja Rosdakarya.

Suherman, Adang. 2009. Model Pembelajaran Pendidikan Jasmani: Alternatif Pengembangan dan Implementasi Model Pembelajaran dalam Pengajaran Penjas, Bandung: FPOK UPI.

Sukintaka. 2004. Teori Pendidikan Jasmani, Bandung: Nuansa. 